\title{
AUTOLOGOUS CHONDROCYTE IMPLANTATION IN BRAZIL
}

\section{IMPLEMENTAÇÃO DO TRANSPLANTE AUTÓLOGO DE CONDRÓCITOS NO BRASIL}

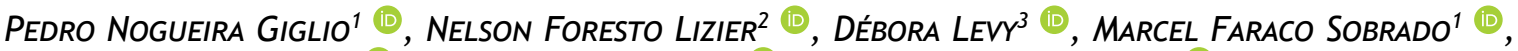

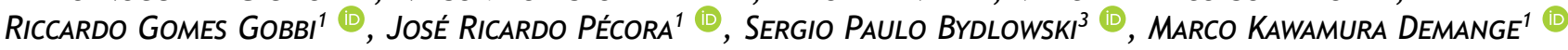 \\ 1. Universidade de São Paulo, School of Medicine, Institute of Orthopedics and Traumatology, (IOT/FMUSP), Sao Paulo, SP, Brazil. \\ 2. Centro de Criogenia Brasil, São Paulo, SP, Brazil. \\ 3. Hospital das Clínicas of the Medical School of Universidade de São Paulo, Instituto do Coração, Immunology Laboratory, Lipids, Oxidation and Cell Biology Group, São Paulo, SP, Brazil.
}

\section{ABSTRACT}

Objective: To describe the first series of cases of autologous chondrocyte implantation $(\mathrm{ACl})$ in collagen membrane performed in Brazil. Methods: $\mathrm{ACl}$ was performed in 12 knees of 11 patients, aged $32.1 \pm 10.9$ years, with $5.3 \pm 2.6 \mathrm{~cm}^{2}$ full-thickness knee cartilage lesions, with a six-month minimum follow-up. Two surgical procedures were performed: arthroscopic cartilage biopsy for isolation and expansion of chondrocytes, which were seeded onto collagen membrane and implanted in the lesion site; the characterization of cultured cells and implant was performed using immunofluorescence for type II collagen (COL2) for cell viability and electron microscopy of the implant. Clinical safety, KOOS and IKDC scores and magnetic resonance imaging were evaluated. We used repeated-measures ANOVA and post-hoc comparisons at $\mathrm{a}=5 \%$. Results: COL2 was identified in the cellular cytoplasm, cell viability was higher than $95 \%$ and adequate distribution and cell adhesion were found in the membrane. The median follow-up was 10.9 months (7 to 19). We had two cases of arthrofibrosis, one of graft hypertrophy and one of superficial infection as complications, but none compromising clinical improvement. KOOS and IKDC ranged from $71.2 \pm 11.44$ and $50.72 \pm 14.10$, in preoperative period, to $85.0 \pm 4.4$ and $70.5 \pm 8.0$, at 6 months $(p=0.007$ and 0.005$)$. MRI showed regenerated tissue compatible with hyaline cartilage. Conclusion: $\mathrm{ACl}$ in collagen membrane was feasible and safe in a short-term follow-up, presenting regenerated formation visualized by magnetic resonance imaging and improved clinical function. Level of evidence IV, Case series.

Keywords: Cartilage. Cell- and Tissue-Based Therapy. Transplantation, Autologous. Chondrocytes.

\section{RESUMO}

Objetivo: Descrever a primeira série de casos de transplante autólogo de condrócitos (TAC) em membrana de colágeno realizada no Brasil. Métodos: Doze joelhos de onze pacientes, com idade de 32,1 \pm 10,9 anos, com lesões de cartilagem de espessura total do joelho de tamanho de 5,3 $\pm 2,6 \mathrm{~cm}^{2}$ foram submetidos ao TAC, com seguimento mínimo de seis meses. Realizamos dois procedimentos cirúrgicos: biópsia artroscópica de cartilagem para isolamento e expansão de condrócitos, que foram semeados em uma membrana de colágeno implantada no leito da lesão. Foi realizada caracterização com imunofluorescência para colágeno tipo II (COL2) de células cultivadas e implantes, viabilidade celular e microscopia eletrônica no implante. Foram avaliados a segurança clínica, os escores funcionais KOOS e IKDC e a ressonância magnética. Utilizamos teste ANOVA para medidas repetidas, com comparações post-hoc, $a=5 \%$. Resultados: $C O L 2$ foi identificado no citoplasma da célula, viabilidade celular foi superior a $95 \%$ e houve distribuição adequada e adesão ce/ular na membrana. O seguimento mediano foi de 10,9 meses (7 a 19). Como complicações, ocorreram dois casos de artrofibrose, um de hipertrofia do enxerto e um de infecção superficial, nenhum deles havendo comprometimento da melhora clínica. Escalas KOOS e IKDC passaram de 71,2 $\pm 11,44$ e 50,72 $\pm 14,10$, no pré-operatório, para 85,0 $\pm 4,4$ e 70,5 \pm 8,0, aos 6 meses ( $p=0,007$ e 0,005). Ressonância magnética mostrou tecido regenerado compatível com cartilagem hialina. Conclusão: TAC em membrana de colágeno foi viável e seguro em seguimento de curto prazo, apresentando formação de regenerado visualizado através de imagens de ressonância magnética e melhora de função clínica. Nível de evidência IV, Série de casos.

Descritores: Cartilagem. Terapia Baseada em Transplante de Células e Tecidos. Transplante Autólogo. Condrócitos.

Citation: Giglio PN, Lizier NF, Levy D, Sobrado MF, Gobbi RG, Pécora JR, et al. Autologous chondrocyte implantation in Brazil. Acta Ortop Bras. [online]. 2020;28(3):131-6. Available from URL: http://www.scielo.br/aob.

Authors declare as conflict of interest that MKD is a medical education consultant for Geistlich Pharma of Brazil.

The study was conducted at Institute of Orthopedics and Traumatology of Hospital das Clínicas of the Medical School of Universidade de São Paulo, at the Genetics and Molecular Hematology Laboratory of Hospital das Clínicas of the Medical School of Universidade de São Paulo, at Centro de Criogenia Brasil. Correspondence: Pedro Nogueira Giglio. Rua Ovídio Pires de Campos, 333, Cerqueira Cesar, São Paulo, SP, Brazil, 05403-010. gigliopedro@gmail.com 


\section{INTRODUCTION}

Articular cartilage defects can impose limiting symptoms, loss of function and predisposition for osteoarthritis. Furthermore, it is a challenging clinical problem, as cartilage damage has limited biological capacity for regeneration. ${ }^{1}$ Nowadays, there are several techniques for treating these injuries with proven medium and long-term clinical results, including bone marrow stimulation (subchondral perforations and microfracture), autologous osteochondral transfer, fresh allogeneic osteochondral transplantation and autologous chondrocyte implantation $(\mathrm{ACl}))^{1,2}$ Each of these techniques has advantages and limitations, but $\mathrm{ACl}$ is currently considered first-line surgical treatment for large defects with intact subchondral bone. ${ }^{3-5}$

$\mathrm{ACl}$ was introduced in 1994 by Brittberg et al. ${ }^{6}$ The procedure is performed in two surgical procedures: arthroscopic biopsy of normal cartilage from a non-weightbearing area, in which chondrocytes are isolated and expanded in a cell culture laboratory; implant of the cultured chondrocytes onto defect site. $\mathrm{ACl}$ first-generation techniqueused a periosteum patch harvested from the tibia and sutured to the surrounding of the defect, containing the solution with suspended cells and delimiting the area for cartilage formation. ${ }^{6}$ Second-generation technique used a collagen membrane to replace the periosteum patch. ${ }^{7}$ Third-generation used previously chondrocytes-seeded membranes, and last days of cell culture are performed directly on the membrane scaffold. ${ }^{8}$

In Brazil, experiences with $\mathrm{ACl}$ and other cellular therapies for cartilage regeneration are incipient. After the initial application of first-generation technique, $, 9,10$ there was a period in which other techniques were not available.

The aim of this study was to establish an $\mathrm{ACl}$ clinical routine for knee cartilage injuries and report the experience with a six-month minimum follow-up, focusing on feasibility, patient safety and evaluation of adverse events and functional outcome.

\section{METHODS}

From January 2017 to December 2018, eleven patients were consecutively recruited to attend an outpatient clinic in a tertiary health service. Inclusion criteria were: aged between 14 and 55 years; and symptomatic chondral knee lesions larger than $2 \mathrm{~cm}^{2}$, visualized on magnetic resonance imaging, classified as III or IV grade by the International Cartilage Regeneration \& Joint Preservation Society (ICRS) score with previous conservative treatment failure. Non-inclusion criteria were: patients with $\mathrm{BMI}>30 \mathrm{~kg} / \mathrm{m}^{2}$ and ligamentous instability or limb malalignment greater than $5^{\circ}$ which were not correctable during surgery. Meniscal deficiency was not an exclusion criterion.

All patients were informed about their voluntary participation in the research by the application of the Informed Consent Form. The study was approved by the Institutional Research Ethics Committee (protocol 1123) and registered in the National Clinical Trials database.

\section{Cartilage biopsy}

In the first surgical stage, cartilage biopsy was performed on the superolateral aspect of the intercondylar notch, outside the loading area. A specific arthroscopic gouge was used to remove a $5 \mathrm{~mm}$ by 10 to $15 \mathrm{~mm}$ full-thickness fragment (Figure 1). The fragment was immediately placed in a $50 \mathrm{ml}$ conical tube containing DMEM / F12 transport culture medium (GIBCO) supplemented with $50 \mu \mathrm{M}$ gentamicin (Hypofarma). The samples were promptly transported to the cell culture laboratory, with facilities approved by the Brazilian national sanitary authority
(ANVISA) for cell therapy clinical trials (Center for Cellular Technology II - CTC II), where they were kept refrigerated at $4^{\circ} \mathrm{C}$ for a maximum of 48 hours.

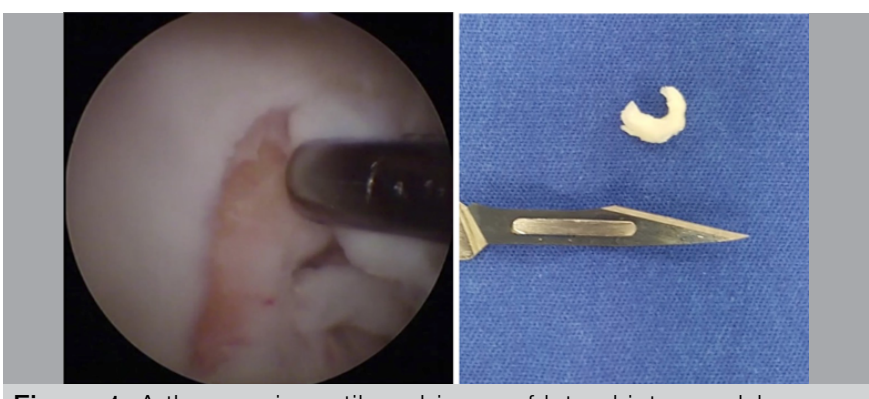

Figure 1. Arthroscopic cartilage biopsy of lateral intercondylar area. Fragment Chondrocyte.

\section{Isolation and culture}

Biopsy specimen was washed three times using phosphorus-buffered saline (PBS) supplemented with $50 \mu \mathrm{M}$ gentamicin and fragmented to obtain small cartilaginous tissue explants. These were placed in $25 \mathrm{~cm}^{2}$ culture bottles, with $5 \mathrm{ml}$ of DMEM/F12 mixture (GIBCO), supplemented with 10\% fetal bovine serum (GIBCO) and $50 \mathrm{uM}$ gentamicin. The bottles were kept in an incubator at $37^{\circ} \mathrm{C}$, with relative humidity close to $100 \%$ and atmosphere of $5 \%$ CO2. After 72 hours, culture medium was changed, and non-adherent fragments were discarded. New culture medium consisted of DMEM/F12 mixture supplemented with $5 \%$ fetal bovine serum and $50 \mu \mathrm{M}$ gentamicin until cells migrated from the explant and formed the first colonies. When maximum confluence (70-90\%) was reached, cell suspension was performed. About $1 \times 10^{4}$ cells per $\mathrm{cm}^{2}$ were placed in culture bottles in DMEM / F12 culture medium supplemented with $5 \%$ fetal bovine serum and $50 \mu \mathrm{M}$ gentamicin until chondrocyte implantation in collagen membrane. Chondrocytes were removed from the culture bottles by TRYPLE enzyme $\left(5 \mathrm{~min}\right.$ at $\left.37^{\circ} \mathrm{C}\right)$ and transferred to $15 \mathrm{ml}$ conical tubes with culture medium supplemented with fetal bovine serum. Then, they were centrifuged at $800 \mathrm{rpm}$ for 5 minutes. Supernatant was discarded and chondrocytes were resuspended in $5 \mathrm{ml} \mathrm{DMEM} \mathrm{/} \mathrm{F12} \mathrm{culture} \mathrm{medium} \mathrm{supplemented}$ with $50 \mu \mathrm{M}$ gentamicin and distributed evenly over the surface of the double-layer type I/III (Chondro-gide ${ }^{\circledR}$ - Geistlich Pharma). ${ }^{11}$ Cultures were kept for 3 to 4 days in an incubator at $37^{\circ} \mathrm{C}$, with relative humidity close to $100 \%$ and atmosphere of $5 \% \mathrm{CO} 2$ until the second surgical procedure..$^{12,13}$

All samples were subjected to quality control. For microbiological control, approximately $2 \mathrm{ml}$ of culture medium was extracted from the chondrocyte culture flasks and added to the microbiological growth flask (BD Bactec Peds Plus ${ }^{\mathrm{TM}}$ ), to detect the growth of aerobic and anaerobic microorganisms in culture medium samples. Fungal culture tests were also performed on culture medium. Immunofluorescence evaluation with human monoclonal antibody anti-collagen was used in cell cultures to assess the presence of type II collagen as a biological marker of chondrocytes. The final implantation of chondrocyte-seeded collagen membrane was subjected to scanning electron microscopy to assess the presence of adhered cells. Cell viability was assessed by DNA-intercalanting assays using hoechst $33342(0.1 \mu \mathrm{g} / \mathrm{ml})$ and iodide propidium (50 $\mu \mathrm{g} / \mathrm{ml})$.

\section{Second surgical stage}

Through a parapatellar knee arthrotomy, the chondral lesion was identified and debrided to remove all injured tissue, 
calcified cartilage layer and any intralesional osteophytes. The objective was to obtain perpendicular edges of healthy cartilage at the edge of the lesion. Then chondrocyte-seeded collagen membrane was implanted with the porous part facing the bed and fixed with absorbable points on the adjacent cartilage and fibrin glue at the lesion bottom and edges. ${ }^{8}$ Additional clinically indicated procedures were performed, as shown in Table 1. Intraoperative clinical images are exemplified in Figures 2 to 4.

Table 1. Patients undergoing autologous chondrocyte implantation.

\begin{tabular}{c|c|c|c|c|c}
\hline Patient & Age & Defect location & Etiology & $\begin{array}{c}\text { Total defect } \\
\text { size }\left(\mathbf{c m}^{2}\right)\end{array}$ & Associated procedures \\
\hline 1 & 31 & LFC & ligament injury & 2.2 & revision ACL reconstruction \\
\hline 2 & 21 & MFC & ligament injury & 3.9 & high tibial osteotomy, ACL reconstruction \\
\hline 3 & 38 & patella MFC & patellar instability & 5.4 & MPFL reconstruction, tibial tuberosity osteotomy \\
\hline 4 & 36 & MFC, LFC, trochlea & ligament injury & 8.2 & $\begin{array}{c}\text { revision ACL reconstruction, anterolateral ligament } \\
\text { reconstruction, medial meniscectomy }\end{array}$ \\
\hline (right knee) & 36 & MFC, LFC, trochlea & ligament injury & 6.7 & revision ACL reconstruction, anterolateral ligament reconstruction \\
\hline left & 27 & patella, trochlea & fracture sequela & 7.6 & - \\
\hline 5 & 34 & MFC & Osteochondritis dissecans & 3.9 & - \\
\hline 6 & 55 & MFC & ligament injury & 8.4 & bone grafting \\
\hline 7 & 14 & trochlear & Osteochondritis dissecans & 2.4 & MPFL reconstruction, tibial tuberosity osteotomy \\
\hline 8 & 25 & patella & patellar instability & 4.7 & ACL reconstruction \\
\hline 9 & 19 & trochlear & ligament injury & 2.1 & valgus tibial osteotomy, ACL reconstruction \\
\hline 10 & 40 & MFC, trochlear & ligament injury & 10.1 & \\
\hline
\end{tabular}

LFC: lateral femoral condyle; ACL: anterior cruciate ligament; MFC: medial femoral condyle; MPFL: medial patellofemoral ligament; SD: standard deviation.
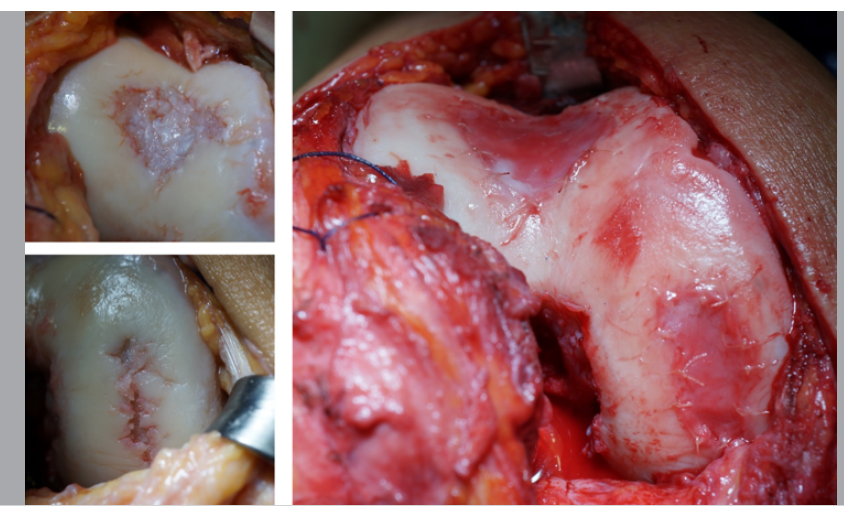

Figure 2. Trochlea and medial femoral condyle injury before and after treatment.
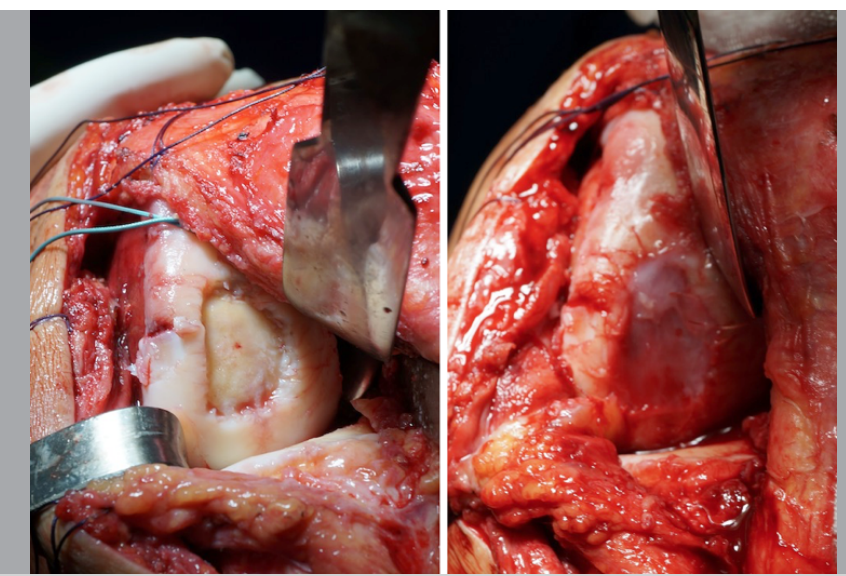

Figure 3. Defect in lateral femoral condyle after debridement and membrane implantation.

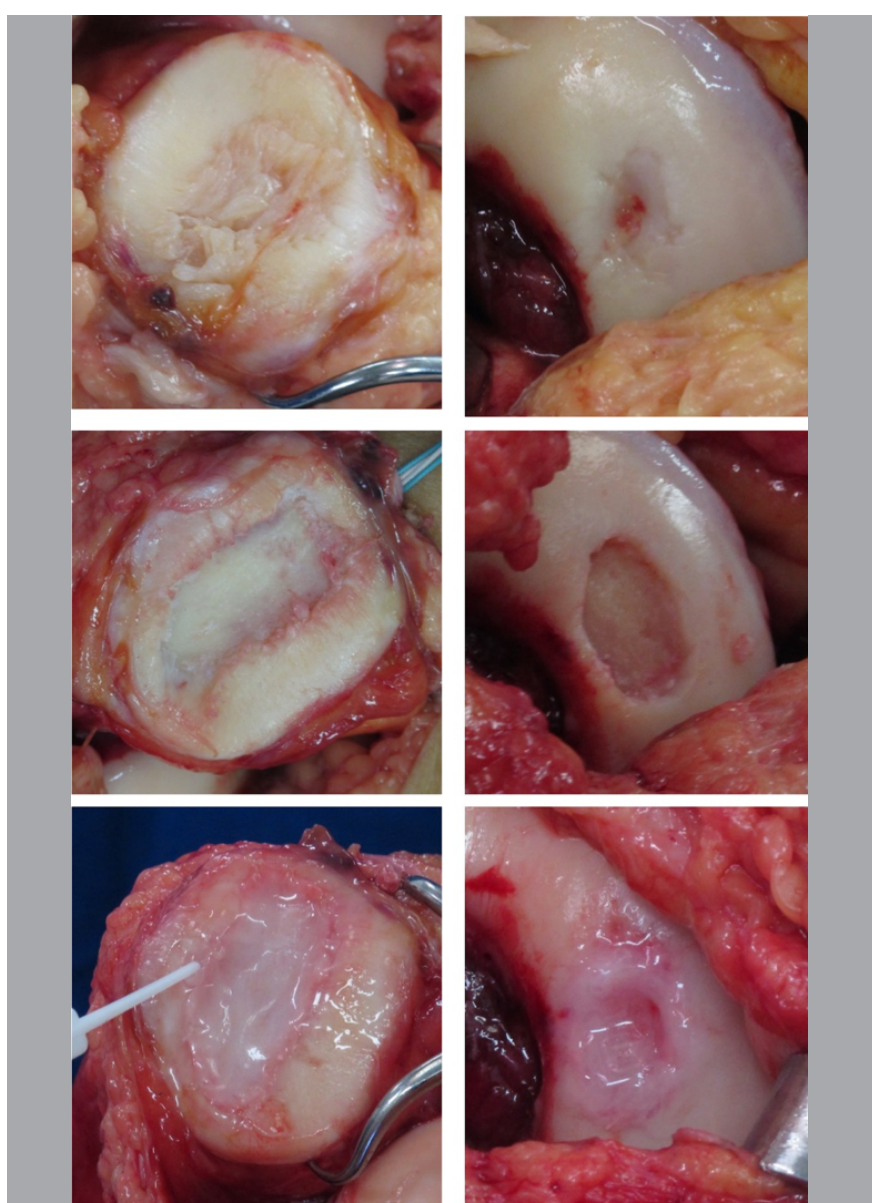

Figure 4. Defects in patella and medial femoral condyle before debridement, after debridement, and after fibrin glue implant. 


\section{Postoperative follow-up}

All patients received initial rehabilitation with assisted gait training with crutches and continuous passive motion (CPM) device at the hospital, for at least three days. For tibiofemoral lesions, immediate partial weightbearing was allowed, progressing to total weightbearing at six weeks. Range of motion (ROM) progression was: $0-30^{\circ}$ in the hospital, $0-90^{\circ}$ up to three weeks, $0-120^{\circ}$ at six weeks, and full ROM after that. For patellofemoral lesions, immediate partial weightbearing with extension immobilizer and crutches was used, progressing to full weightbearing at three weeks and immobilizer removal at six weeks. ROM progression was: $0-20^{\circ}$ at admission, $0-60^{\circ}$ at three weeks and $0-120^{\circ}$ up to six weeks. Running started between 9 and 12 months, and normal sports activities after 12 to 18 months.

KOOS (Knee injury and Osteoarthritis Outcome Score) and IKDC (International Knee Documentation Committee Score) functional outcomes questionnaires were used. ${ }^{14} \mathrm{~T} 2$-mapping magnetic resonance images were performed after six months for all patients.

Preoperative and postoperative patient's functional scores were compared. Repeated-measures ANOVA and Bonferroni method for multiple comparisons were performed using the SPSS 22 statistical package (IBM, New York) to verify statistically significant differences. Results were expressed as mean \pm standard deviation for normal distribution variables, considering a statistically significant $P$ value $<0.05$

\section{RESULTS}

Twelve knees of eleven patients aged $32.1 \pm 10.9$ years underwent treatment. Average size of lesions was $5.3 \pm 2.6 \mathrm{~cm}^{2}$. Location and associated lesions treated are summarized in Table 1. Patient's median follow-up was 10.9 months (7 to 19). Two patients followed up for less than two months by our group were not included in this series. We were successful in isolating and culturing all biopsy specimens performed. Average cell culture period was 35 days. There was no microbiological contamination in any of the samples. Immunofluorescence images of cultured chondrocytes showed the presence of type II collagen distributed throughout the cell cytoplasm, demonstrating chondrogenic profile (Figure 5). Membrane scanning electron microscopy at the time of implantation showed the presence of chondrocytes uniformly adhered to the membrane matrix through thin cytoplasmic extensions (Figure 6). There was good cell distribution in the membrane, and cell viability tests showed at least $95 \%$ of viable cells (Figure 7 ).

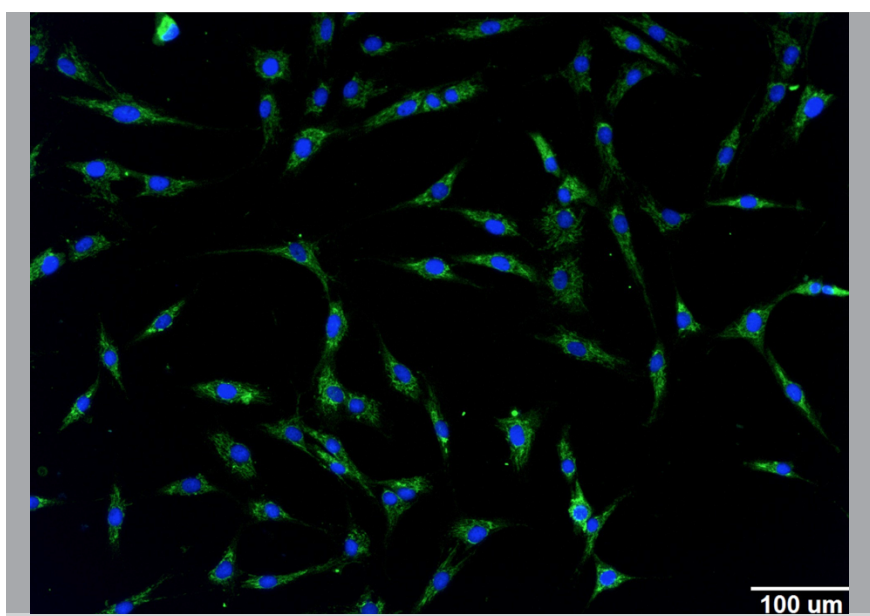

Figure 5. Immunofluorescence showing type II collagen in the cytoplasm of cultured chondrocytes.

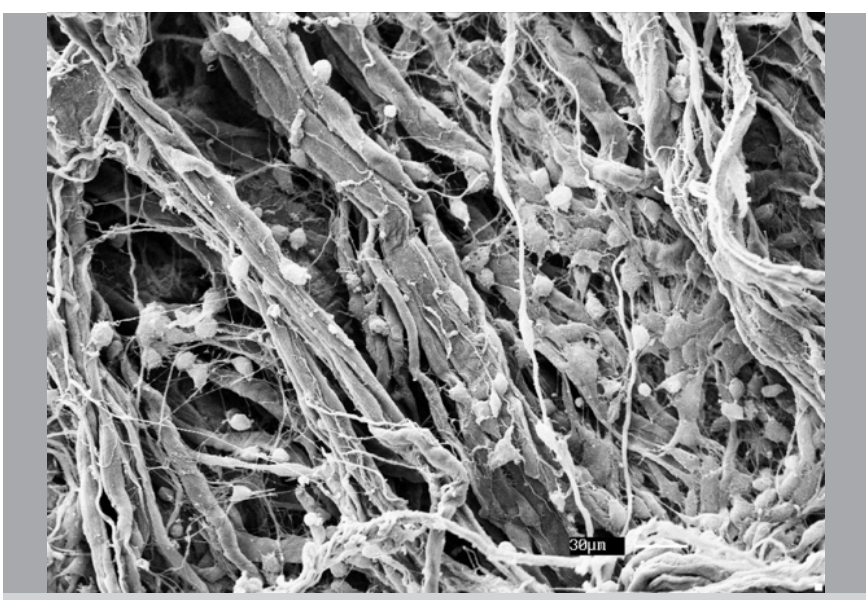

Figure 6. Scanning electron microscopy image showing chondrocytes adhered to the membrane collagen fibers.

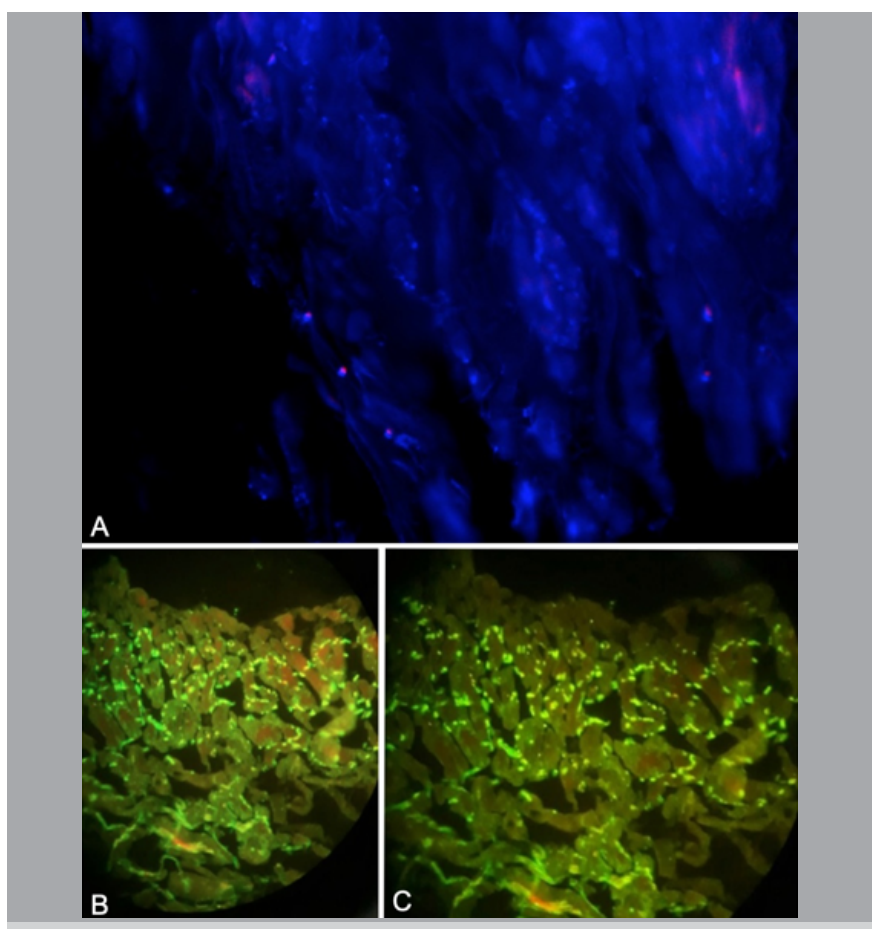

Figure 7. (A) DNA-intercalanting assay showing cell viability greater than $95 \%$. (B, C) Immunofluorescence with human anti-collagen II monoclonal antibody in the final implant, showing presence and cellular distribution in membranes.

Functional results are summarized in Table 2 and Figure 8 . KOOS and IKDC scales were $71.2 \pm 11.44$ and $50.72 \pm 14.10$ preoperatively; at three months $77.7 \pm 16.2$ and $62.3 \pm 19.2$; and six months $85.0 \pm 4.4$ and $70.5 \pm 8.0 . \mathrm{KOSS}(\mathrm{p}=0.031)$ and IKDC $(p=0.009)$ scores were significantly differentbetween preoperative and 6-month scores ( $p=0.007$ for KOOS and $p=0.005$ for IKDC).

Table 2. Preoperative clinical scores at three and six months of follow-up.

\begin{tabular}{c|cc|cc|cc|c|c}
\hline & Preoperative & \multicolumn{2}{|c|}{$\begin{array}{c}\text { three } \\
\text { months }\end{array}$} & \multicolumn{2}{c|}{$\begin{array}{c}\text { six } \\
\text { months }\end{array}$} & $p^{*}$ & $\begin{array}{c}\mathrm{p} \text { (preop vs } \\
6 \text { months) } \dagger\end{array}$ \\
\hline KOOS & 71.2 & 11.44 & 77.7 & 16.2 & 85.0 & 4.4 & $\mathrm{p}=0.031 \ddagger$ & $\mathrm{p}=0.007 \ddagger$ \\
\hline IKDC & 50.72 & 14.10 & 62.3 & 19.2 & 70.5 & 8.0 & $\mathrm{p}=0.009 \ddagger$ & $\mathrm{p}=0.005 \ddagger$ \\
\hline
\end{tabular}

KOOS: Knee Injury and Osteoarthritis Outcome Score; IKDC: International Knee Documentation Committee Score. *Repeated-measures ANOVA with Greenhouse-Geisser correction; † Bonferron correction t-test; ‡ statistically significant. 


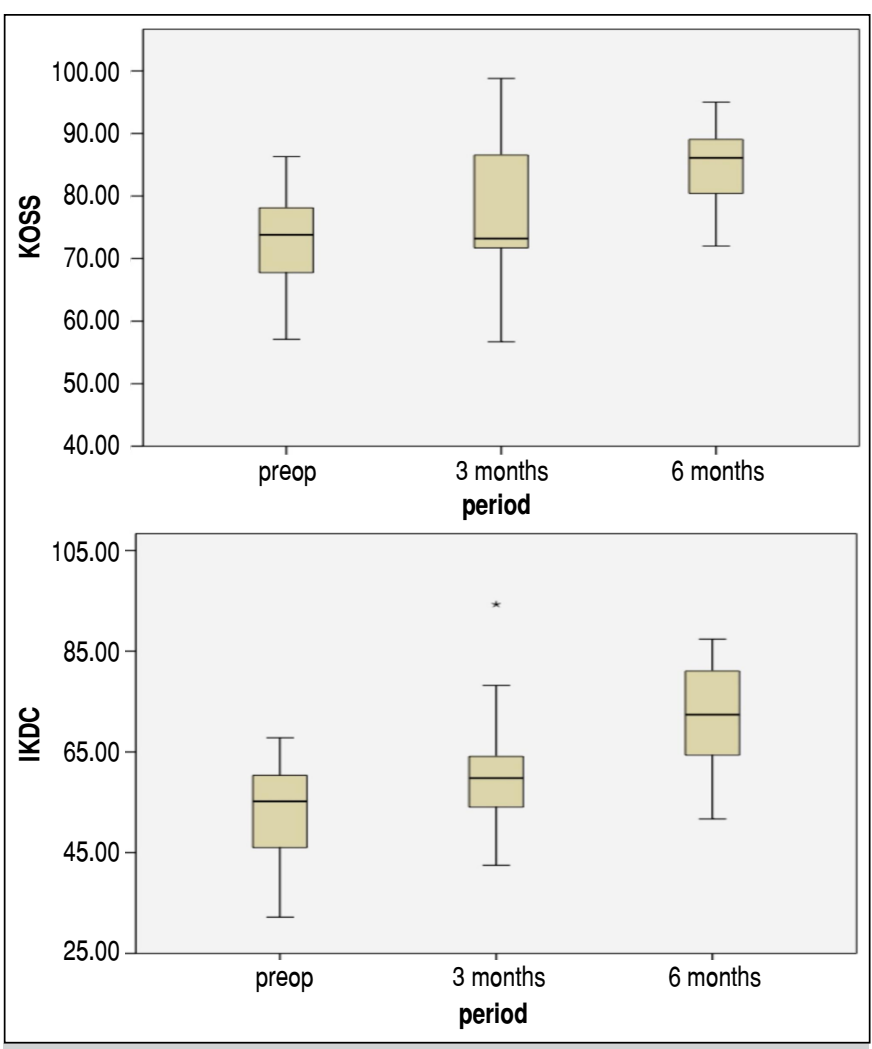

Figure 8. Box charts for the evolution of preoperative KOOS and IKDC scores at six weeks, three months and six months.

Magnetic resonance imaging at six-month follow-up showed regenerated tissue at lesion site, good filling and signs of compatibility with hyaline cartilage (Figures 9 and 10).
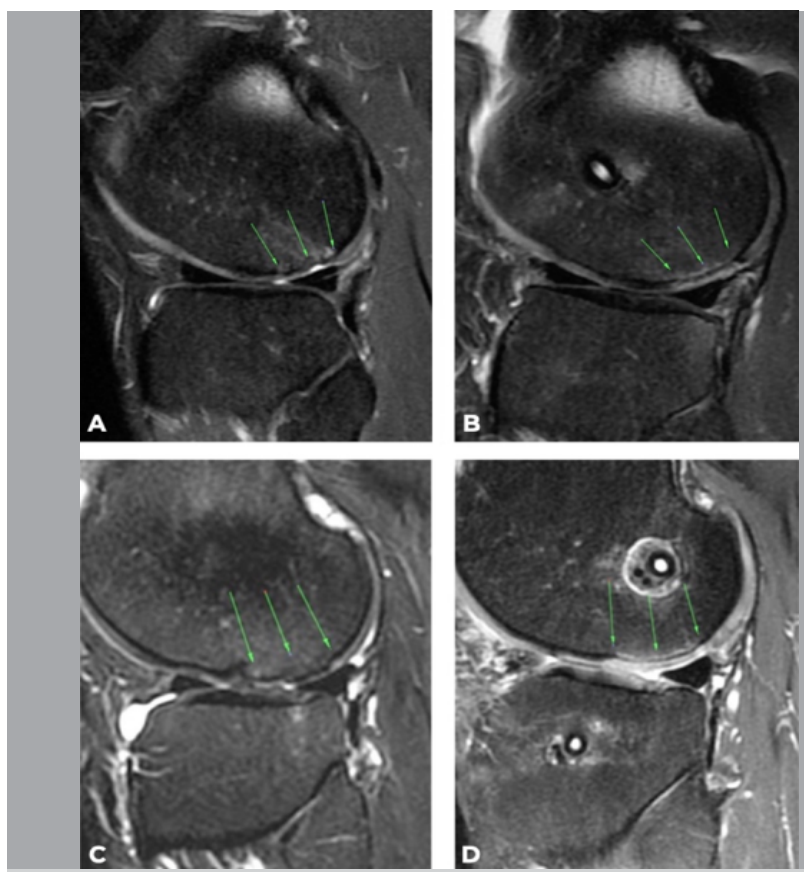

Figure 9. Images demonstrating lateral femoral condyle lesions of two patients. Images $\mathrm{A}$ and $\mathrm{C}$ are preoperative, showing chondral lesion, bone edema and intra-lesional osteophytes; images B and D show the evolution at 6 months, good filling regeneration and signs of compatibility with hyaline cartilage.

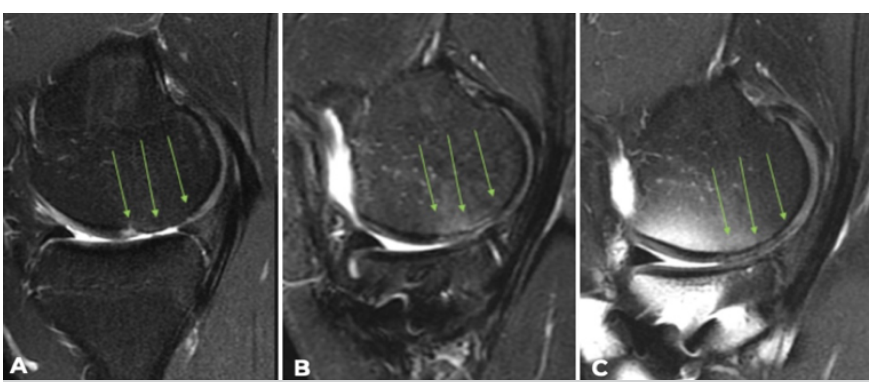

Figure 10. Preoperative magnetic resonance images $(A)$, six months (B) and one year (C) patient follow-up. 1. Increased lesion filling and regeneration, similar to adjacent cartilage on the one-year image.

There were four cases of complication. Two patients presented stiffness and difficulty in ROM progression, with flexion less than 120 degrees at the tenth week. After arthroscopic release and joint manipulation, full ROM was achieved. One patient presented dehiscence and superficial infection in a pelvic surgical wound for iliac graft removal, used for a high tibial osteotomy. He was treated with wound debridement and antibiotic therapy until complete resolution. There was only one complication due to the chondrocyte implantation itself: a graft hypertrophy observed through magnetic resonance imaging but asymptomatic.

\section{DISCUSSION}

This study reported the first cases of third-generation $\mathrm{ACl}$ using collagen membrane in Brazil.

Isolation and cell cultivation of samples from all patients were successful on chondrocyte growth and positive expression of collagen type II. The quality control of the implants demonstrated good distribution, viable cells adhering to the extracellular matrix of the collagen membrane and no microbiological contamination. The primary outcome assessed in this short-term follow-up was safety. All surgeries were performed successfully. Although there were four cases of treatment complications, all were successfully treated, without functional outcome impairment. Three cases were due to complex reconstructive knee surgery: post-operative stiffness and wound complication. Only one was related to the implantation itself, with graft hypertrophy observed through magnetic resonance imaging, but not presenting symptoms. This complication has been reported in $\mathrm{ACl}$ international literature as occurring in up to $27 \%$ of cases, ${ }^{15}$ and unrelated to clinical outcomes or cartilage quality. ${ }^{15,16}$ The functional result obtained was adequate until the sixth month, with KOOS and IKDC scores improvement in relation to the preoperative, consistent with previous literature. Gommol et al. ${ }^{17}$ reported an increase in IKDC from 45.6 to 68, and KOOS from 45.86 to 70.14 in 2.46 years. Saris et al. ${ }^{18}$ reported an increase in IKDC 32.9 to 65.7, and KOOS from 32.5 to 74.1 in 24 months.

As in other literature series, we expect function to improve further with longer follow-ups, as returning to sports activities takes long after $\mathrm{ACl}$ application, fully allowed after 12 to 18 months. ${ }^{13,19}$

Our study has limitations. This is a case series with no control group and short-term follow-up. To evaluate the effectiveness of cartilage treatments, a minimum two-year follow-up is desirable. However, the work was fully adequate to its main objective: to report the development of a clinical routine for $\mathrm{ACl}$ with feasibility and safety evaluation as a secondary outcome for the initial efficacy. At this follow-up, it was possible to observe the regeneration in imaging exams, initial clinical improvement in all patients and no serious complications.

Patients recruited for this study represent the reality of cartilage treatment defects in Brazil: large chondral lesions requiring additional procedures to treat associated lesions. Using patients with isolated 
chondral lesion would result in less varied outcomes. However, for the evaluation of safety and effectiveness, we preferred to include the patient profile in which the technique is most likely to be applied in our country, including associated injuries and previous surgeries. We expect $\mathrm{ACl}$ to be frequently used as a combined procedure, and even as a salvage one, after several previous surgeries. Therefore, this choice increases the external validity of our study. ${ }^{20}$

$\mathrm{ACl}$ is considered a first-line method in the international literature for the treatment of large unipolar chondral knee injuries in active patients. ${ }^{4,5}$ With third-generation technique, chondrocyte adhesion in scaffold occurred in vitro, needless of cell manipulation in the operating room. ${ }^{4,21}$

Cell therapy as a treatment for cartilage injury has generated widespread clinical and research interest worldwide. ${ }^{22} \mathrm{ACl}$ was the first cell therapy for cartilage defects developed and routinely used worldwide and is a first-line therapy for large chondral lesions. Gaining national experience allows us to glimpse the possibility of having this technique available for routine clinical use in near future. It is also the first necessary step towards the future of cell and orthobiologic therapy in Brazil.

\section{CONCLUSION}

$\mathrm{ACl}$ in collagen membrane was feasible and safe in short-term follow-up for the treatment of cartilage defects larger than $2 \mathrm{~cm}^{2}$, presenting regenerated formation, visualized through magnetic resonance imaging, and improvement of clinical function.

\section{Acknowledgments}

The authors thank Rose Eli Grassi Rici, Lucas da Ponte Melo, Luis Eduardo Passareli Tirico, Camilo Partezani Helito, Marcelo Batista Bonadio, and Walcy Rosolia Teodoro for the essential contributions to this study. The authors also thank Centro de Criogenia Brasil (CCB) for their collaboration, including the use of cell culture laboratory structure.

AUTHOR'S CONTRIBUTIONS: Each author contributed individually and significantly to the development of this article: PNG: management, surgical procedures, statistical analysis, data interpretation, conception, article review; NFL: cell culture procedures, drafting, review; DL: laboratory analytical procedures, cell characterization, drafting, review; MFS: clinical functional evaluation of patients; RGG: management, surgical procedures, article review; JRP: management, data interpretation, discussion, article review; SPB: management, cell characterization, article review; MKD: article conception and management, data interpretation, drafting, article review.

\section{REFERENCES}

1. Minas T. A primer in cartilage repair. J Bone Joint Surg Br. 2012;94(11A):141-6.

2. Huang BJ, Hu JC, Athanasiou KA. Cell-based tissue engineering strategies used in the clinical repair of articular cartilage. Biomaterials. 2016;98:1-22.

3. Moran CJ, Pascual-Garrido C, Chubinskaya S, Potter HG, Warren RF, Cole BJ, Rodeo SA. Restoration of articular cartilage. J Bone Joint Surg Am. 2014;96(4):336-44.

4. Hinckel BB, Gomoll AH. Autologous chondrocytes and next-generation matrix-based autologous chondrocyte implantation. Clin Sports Med. 2017;36(3):525-48.

5. Ozmeriç A, Alemdaroğlu KB, Aydoğan NH. Treatment for cartilage injuries of the knee with a new treatment algorithm. World J Orthop. 2014;5(5):677-84.

6. Brittberg M, Lindahl A, Nilsson A, Ohlsson C, Isaksson O, Peterson L. Treatment of deep cartilage defects in the knee with autologous chondrocyte transplantation. N Engl J Med. 1994;331(14):889-95.

7. Haddo O, Mahroof S, Higgs D, David L, Pringle J, Bayliss M, et al. The use of chondrogide membrane in autologous chondrocyte implantation. Knee. 2004;11(1):51-5.

8. Behrens P, Bitter T, Kurz B, Russlies M. Matrix-associated autologous chondrocyte transplantation/implantation (MACT/MACI)-5-year follow-up. Knee. 2006;13(3):194-202.

9. Gobbi RG, Demange MK, Barreto RB, Pécora JR, Rezende MU, Barros Filho TEP, Lombello CB. Autologous chondrocyte implantation: series of 3 cases. Rev Bras Ortop. 2015;45(4):449-55.

10. Cohen $M$, Nery C, Peccin MS, Réssio CR, Asaumi ID, Lombello CB. Implante autólogo de condrócitos para o tratamento de lesão do côndilo femoral e talo. Einstein. 2008;6(1):37-41.

11. Registro ANVISA $n^{\circ} 80696930011$ - CHONDRO GIDE ${ }^{\circledR}$ [Internet]. Brasília, DF: Agência Nacional de Vigilância Sanitária; [updated 2020 Mar 18; cited 2020 Mar 20]. Available from: https://www.smerp.com.br/anvisa/?ac=prodD etail\&anvisald=80696930011

12. Zheng MH, Willers C, Kirilak L, Yates $P$, Xu J, Wood D, Shimmin A. Matrix-induced autologous chondrocyte implantation (MACl): biological and histological assessment. Tissue Eng. 2007;13(4):737-46.
13. Edwards PK, Ackland TR, Ebert JR. Accelerated weightbearing rehabilitation after matrix-induced autologous chondrocyte implantation in the tibiofemoral joint: early clinical and radiological outcomes. Am J Sports Med. 2013;41(10):2314-24.

14. Hoemann C, Kandel R, Roberts S, Saris DBF, Creemers L, Mainil-Varlet P, et al. International cartilage repair society (ICRS) recommended guidelines for histological endpoints for cartilage repair studies in animal models and clinical trials. Cartilage. 2011;2(2):153-72.

15. Ebert JR, Smith A, Fallon M, Butler R, Nairn R, Breidahl W, Wood DJ. Incidence, degree, and development of graft hypertrophy 24 months after matrix-induced autologous chondrocyte implantation: association with clinical outcomes. Am J Sports Med. 2015;43(9):2208-15.

16. Niethammer TR, Loitzsch A, Horng A, Baur-Melnyk A, Bendiks M, Gülecyüz MF, et al. Graft hypertrophy after third-generation autologous chondrocyte implantation has no correlation with reduced cartilage quality: matched-pair analysis using T2-weighted mapping. Am J Sports Med. 2018;46(10):2414-21.

17. Gomoll AH, Ambra LF, Phan A, Mastrocola M, Shah N. Cell-seeded autologous chondrocyte implantation: a simplified implantation technique that maintains high clinical outcomes. Am J Sports Med. 2017;45(5):1028-36.

18. Saris D, Price A, Widuchowski W, Bertrand-Marchand M, Caron J, Drogset JO, et al. Matrix-applied characterized autologous cultured chondrocytes versus microfracture: two-year follow-up of a prospective randomized trial. Am J Sports Med. 2014;42(6):1384-94.

19. Edwards PK, Ackland T, Ebert JR. Clinical rehabilitation guidelines for matrix-induced autologous chondrocyte implantation on the tibiofemoral joint. J Orthop Sports Phys Ther. 2014;44(2):102-19.

20. Rothwell PM. External validity of randomised controlled trials: "to whom do the results of this trial apply?". Lancet. 2005;365(9453):82-93.

21. Goyal D, Goyal A, Keyhani S, Lee EH, Hui JH. Evidence-based status of secondand third-generation autologous chondrocyte implantation over first generation: a systematic review of level I and II studies. Arthroscopy. 2013;29(11):1872-8.

22. Caldwell KL, Wang J. Cell-based articular cartilage repair: the link between development and regeneration. Osteoarthritis Cartilage. 2015;23(3):351-62. 